\title{
White Pine Blister Rust in British Columbia I. The Possibilitties of Control by Branch Removal
}

by

R.S. Hunt ${ }^{1}$

\begin{abstract}
White pine blister rust (Cronartium ribicola J.C. Fisch. ex Rab.) branch cankers on 12. to 30-year-old western white pines (Pinus monticula Dougl.) in British Columbia were measured for distance from the stem, and cankers on branches and stems were measured for height above ground. Most stem cankers originated from branch cankers within $60 \mathrm{~cm}$ of the stem and within $\mathbf{2 . 5} \mathrm{m}$ of the ground. Trees on slopes tended to have cankers higher into the crown than those on flat sites. Removal of lower branches from young western white pines will greatly reduce the possibility of death from blister rust infection. Treatment recommendations are given for western white pine as a minor or major component of the stand.
\end{abstract}

\section{Keywords: Cronartium; Pinus monticola}

\section{Résumé}

Des chancres causés par le Rouille vésiculeuse du pin blanc (Cronartium ribicola J.C. Fisch ex. Rab.) sur le houppier de certains pins argentés Pinus monticola Dougl.) âgés de 12 à 30 années en Colombie. Britannique, ont été mesurés pour en déterminer la distance au fût. La hauteur à partir du sol des chancres présents tant sur les branches que sur le fût a été ensuite mesurée. La plupart des chancres du fût provenaient des chancres du houppier situés deçà de $\mathbf{6 0}$ $\mathrm{cm}$ du fût et de $250 \mathrm{~cm}$ du sol. Les arbres venant sur des pentes tendaient à avoir des chancres à des points plus élevés dans la cime que ceux venant sur des terrains plats. L'enlèvement des branches basses chez les jeunes pins argentés réduira considérablement la probalité de mortalité par suite de la Rouille vésiculeuse. Des recommandations sont fournies relativement au traitement pour différentes conditions de peuplement.

\section{Mots clés: Cronartium; Pinus monticola}

\section{Introduction}

The control of white pine blister rust (Cronartium ribicola J.C. Fisch. ex Rab.) on eastern white pine (Pinus strobus L.) by lower branch removal (Brown 1972) is successful in eastern United States because environmental factors apparently limit most blister rust cankers to within $1.80 \mathrm{~m}$ of the ground (Van Arsdel et al. 1961). In Oregon, blister rust of sugar pine ( $P$. lambertiana Dougl.) can be controlled by branch removal if done to a height of about $5.5 \mathrm{~m}$ (Hayes and Stein 1957). Recently, stem infections on western white pine ( $P$. monticola Dougl.) in Idaho were reduced by about $40 \%$ following two separate branch removal operations (Martin et al. 1980). Cursory observations in British Columbia suggested that the majority of infections are closer to

2Pacific Forest Research Centre, Canadian Forestry Service, 506 West Burnside Road, Victoria, BC V8Z 1 M5. the ground than in Idaho and therefore branch removal may be a more attractive control than it is in that state.

The objectives of this study were to determine the distribution of blister rust cankers on young western white pine in British Columbia and optimum tree size for maximum pruning benefits.

\section{Methods}

Sampling strips were established to sample trees and microsites representative of a stand in all biogeoclimatic zones in which western white pine occurs in British Columbia (Krajina 1969). Twenty well-spaced trees in each of six diameter classes (see below) were sought and the heights were estimated in 26 second-growth stands, 12-30 years old. In many stands, 20 trees in classes above $15 \mathrm{~cm}$ could not be found along the samplng strip; therefore, the total ampling size among stands is not uniform (Fig. 1): In cankered trees height above ground for all stem (S-) cankers were recorded.

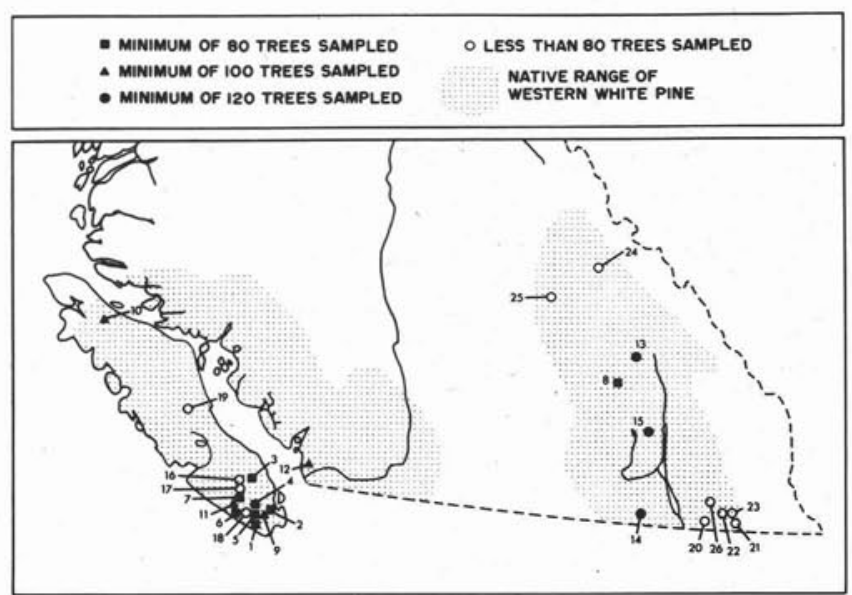

Figure 1. Locations of stands sampled for white pine blister rust in British Columbia.

"Threatening" (T-) cankers (Childs and Kimmey 1938) on branches within $60 \mathrm{~cm}$ of the stem were recorded, with height above ground. Condition of cankered branches was classed as a) alive, b) dying (if dead at distal end), or c) dead.

Additionally, trees killed by the rust were classed by diameter and height above ground of S-cankers recorded.

Trees were classed by dbh $(1.4 \mathrm{~m})$ as follows:
a) trees less than $1.4 \mathrm{~m}$ high
b) $.1 \cdot 4.9 \mathrm{~cm}$ (average $3 \mathrm{~m}$ high)
c) $5 \cdot 9.9 \mathrm{~cm}$ (average $6 \mathrm{~m}$ high)
d) $10-14.9 \mathrm{~cm}$ (average $9 \mathrm{~m}$ high)
e) $15-19.9 \mathrm{~cm}$ (average $12 \mathrm{~m}$ high)
f) $20-24.9 \mathrm{~cm}$ (average $15 \mathrm{~m}$ high)

\section{Results}

Data were gathered on 1809 cankers. Most Scankers (87.3) began as branch cankers, and no S-cankers originated from branch cankers where the point of origin was more than $60 \mathrm{~cm}$ from the stem. S-cankers were close 
to the ground; even on the taller trees the majority of the $\mathrm{S}$-cankers were within $1.25 \mathrm{~m}$ of the ground (Table 1). In most stands, only a few of the S-cankers were above $2.5 \mathrm{~m}$ (many of these not much higher). Exceptions were found in stands on steep slopes, where there was a tendency for S-cankers to be found higher in the tree as the slope increased (Table 1).

Table 1. Distribution of Cronartium ribicola stem cankers on western white pines in three height classes.

\begin{tabular}{rccc}
\hline Stand * & \multicolumn{3}{c}{ No. of trees with cankers: } \\
\cline { 2 - 4 } & below $\mathbf{1 . 2 5} \mathbf{~ m}$ & $\mathbf{1 . 2 5} \mathbf{2 . 5} \mathbf{~ m}$ & above $\mathbf{2 . 5} \mathbf{~ m}$ \\
\hline 10 & 2 & 4 & 1 \\
1 & 9 & 0 & 1 \\
5 & 7 & 1 & 1 \\
$12 \dagger$ & $£$ & 5 & 2 \\
$15 \dagger$ & 4 & 4 & 2 \\
$2 \dagger$ & 8 & 3 & 1 \\
$20 \dagger$ & 6 & 4 & 4 \\
$4 \dagger$ & 6 & 1 & 3 \\
13 & 5 & 1 & 5 \\
14 & 1 & 2 & 5 \\
Total & 52 & 25 & 25 \\
\hline
\end{tabular}

*All stands sampled, with a sample size of 20 living trees $10+m$ high. Stands arranged from very flat $(10)$ to very steep (14). For stand locations see figure 1.

tTypical site rolling hills to moderate slopes (15-50\%).

Few T-cankers were found on trees in the a) diameter class and few cankers were recorded in the first $30 \mathrm{~cm}$ above ground in all diameter classes. Above $30 \mathrm{~cm}$, there was a slight tendency for T-cankers to be found higher as the tree increased in size; however, the distribution pattern was similar to S-cankers, the flattest sites (Table 1, stand No. 1 and 10), moderate sloped sites (Table 1, stand No. $2,4,12,15,20$ ), and steepest sites (Table 1, stand No. 13 and 14) having 3,11 and $27 \%$, respectively, of the T-cankers above $2.5 \mathrm{~m}$, with most below $1.25 \mathrm{~m}$. As the trees increased in size, there was a tendency for the number of dead and dying branch cankers to increase; for example, the mean number of live T-cankers for the stands on moderate slopes (Table 1, No. 2,4,12,15,20) in the $0.1-4.9 \mathrm{~cm}$ diameter trees (.61) was twice that in the $15-19.9 \mathrm{~cm}$ diameter trees (.28), although a similar percentage of trees had infections $(52 \%$ and $59 \%$, respectively).

\section{Discussion}

The distribution of blister rust cankers in western white pine trees, in British Columbia was similar among stands in that most of the cankers were close to the ground. The difference among stands was characterized by slope, flatter sites tending to have more cankers closer to the ground and steeper sites tending to have more cankers higher up the tree. Branch removal would therefore be less effective on the steeper sites.

Most western white pine in British Columbia grows on moderate slopes, $(15-50 \%)$ and the effect of branch removal from trees on these sites can be calculated. By using the data, the proportion of trees i) free of S- cankers, or ii) with S-cankers or iii) dead can be determined for a particular diameter or height class; for example, for 100 trees in the 4-to 5-m-height class, 48 will be free of S-cankers, 37 will have S-cankers and 15 will have died from blister rust. Of these trees, 85 can grow into the next height class; the survival rate can then be estimated from the observed amount of cankering in the next height class. In turn, subsequent survival can be estimated from the taller height classes (Fig. $2 A)$. By knowing the height at which cankers entered the stem, one can predict a lesser rate of mortality and becoming S-cankered, if the T-cankers had been successfully removed. Improved survival is obtained by branch removal farther up the tree and as early as possible (Fig. 2).
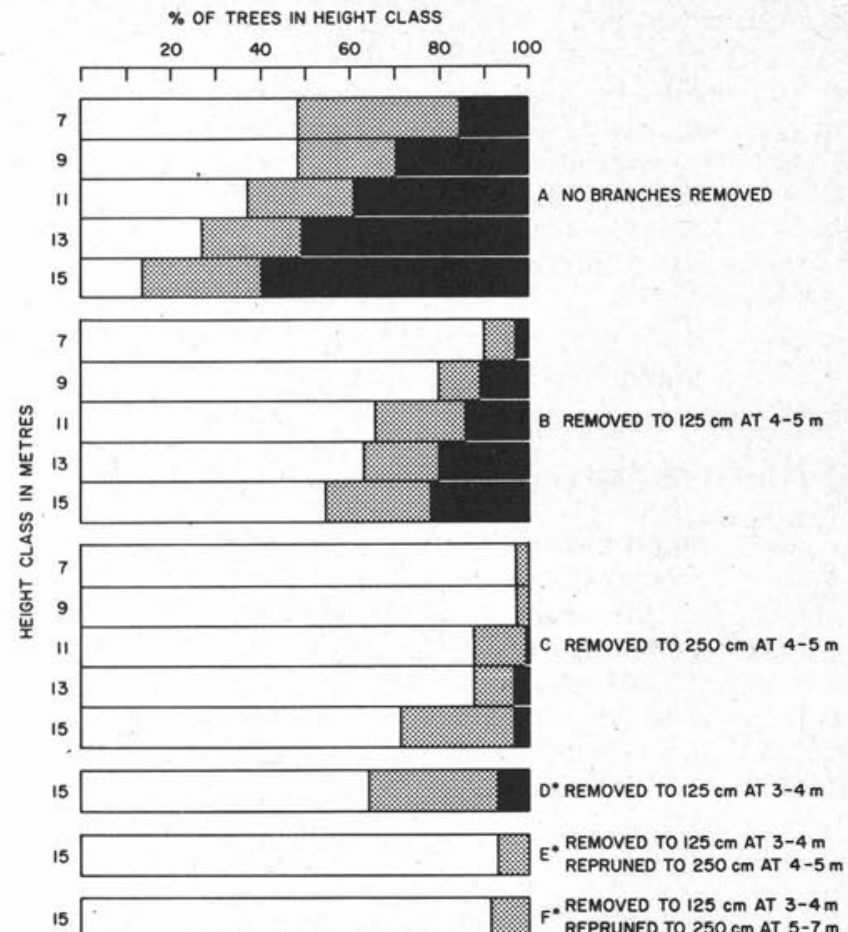
REPRUNED TO $250 \mathrm{~cm}$ AT 5-7 $\mathrm{m}$

LACKING STEM CANKERS STEM CANKERS DEAD

-earler pruning increases the initial survival by $32 \%$

Figure 2. The effect of branch removal on the theoretical survival of 100 healthy western white pine, $4.5 \mathrm{~m}$ height, as calculated from data from five typical young growth stands (No. $2,4,12,15,20$ ). The sample size per height class ranges from $30-79$

If all branches up to a height of $1.25 \mathrm{~m}$ were removed from 4-to 5-m-tall western white pine in stands on moderate slopes, survival should double (Fig. 2A and B) and branch removal to a height of $2.5 \mathrm{~m}$ could cut future losses from 60 to a few per cent (Fig. 2A and C). Earlier branch removal, i.e., when trees are 3-to $4-\mathrm{m}$ tall to a height of $1.25 \mathrm{~m}$, is almost as effective as later branch removal to a height of 2.5 $\mathrm{m}$ when trees are 4-to 5-m tall (Fig. $2 \mathrm{C}$ and $\mathrm{D}$ ), because many trees in the 4-to $5-\mathrm{m}$ class would already have $\mathrm{S}$-cankers if branches had not been removed. Removing an additional $1.25 \mathrm{~m}$ from 3-to $4-\mathrm{m}$ tall trees at a later date could reduce blister rust losses to a negligible amount (Fig. $2 \mathrm{E}$ and $\mathrm{F}$ ). Timing of the second treatment does not appear critical (Fig. 2E and F); however, in general, the earlier the branches are removed the sooner the rust is stopped, but on steeper sites there could be an advantage in delaying the second treatment so that trees could have branches removed farther up than $2.5 \mathrm{~m}$.

Trees in the $5-9.9 \mathrm{~cm}$ diameter class had more active cankers than larger trees. Many of the T-cankers on larger trees $(15 \mathrm{~cm}+$ diameter class) had already grown into the stem of had died and thus the trees escaped S-infection. Removing branches from the larger trees would then be much less effective than from trees in the $.1-9.9 \mathrm{~cm}$ diameter classes (3-6 $\mathrm{m}$ height classes).

The theoretical gain from branch removal will be affected both positively and negatively. The negative aspect is the possibility that some removed T-cankers, which apparently have not reached the stem, have in fact infected the stem. There are two positive aspects: first, canker removal will reduce the perennial inoculum, which should reduce the risk of future damage in the stand, and second, any infections above the height to which branches are removed, can be observed and removed during the treatment. The gain from 
both these factors is greatest when treating young trees (2.5.4 $\mathrm{m}$ high) to only $1.25 \mathrm{~m}$.

Because it is difficult and time-consuming to search for rust cankers low down on western white pine trees, it is easier and faster to remove all branches to a fixed height than it is to remove only infected ones. Removing all branches to a fixed height rather than pruning out cankers or removing infected branches also removes potential infection courts that could result in S-cankers. T-cankers are more confidently eliminated by branch removal as close to the stem as possible.

\section{Recommendations}

Observations indicate that stands of western white pine with a dbh of $35-45 \mathrm{~cm}$ and very little blister rust mortality can be grown if branches are removed following the recommendations below. At this time, stands on steeper slopes can be expected to show stem cankering in the crown, and perhaps some dead tops. Harvesting should be considered at this time, whereas western white pine in stands on flatter sites would have little evidence of cankering and harvesting can be delayed.

\section{When western white pine occurs as a component of a mixed stand:}

For optimum benefits, trees 2.5-to 5-m tall, should have all branches removed for at least the first $1.25 \mathrm{~m}$. Higher infected branches should also be removed. The optimum time for observing cankered branches is mid-April through May, when the orange aeciospores are conspicuous. All trees with resinous patches on the stem or other indications of S infection will die before merchantable size and should be removed. These treatments can usually be incorporated with thinning operations.

When young growth western white pine is the major component of the stand such as in plantations:

Two treatment times are recommended. The first branch removal, when the trees are about $2.5 \mathrm{~m}$ tall, should be to $1.25 \mathrm{~m}$, with diseased branches above this height removed. The second branch removal, when the trees are about $4 \mathrm{~m}$ tall, should be to a height of $2.5 \mathrm{~m}$; again remove additional infected branches above this height. In both cases, the few trees with S-cankers should be removed.

\section{References}

Brown, H.D. 1972. Guidelines: Pruning white pine in the Lake States for blister rust control. US For. Serv., S \& PF, St Paul, MN, S-72-9, 12 p.

Childs, T.W., and J.W. Kimmey. 1938. Studies on probable damage by blister rust in some representative stands of young western white pine. J. Agr. Res. 57: 557-568

Hayes, G.S., and W.I. Stein. 1957. Eliminating blister rust cankers from sugar pine by pruning. US For. Serv., Pac. N.W. For. \& Range Exp. Stat. Res. Note 151, 8 p.

Krajina, V.J. 1969. Ecology of forest trees in British Columbia. Ecol. of West. N. Am. 2: 1-147

Martin, N.E., R.E. Williams, and J.Y. Woo. 1980. Infection intensity in the Johnson Draw Plantation after 10 years of blister rust management through pruning and thinning of western white pine. Abstr. no. 529 at the joint meeting of the Am. and Can. Phyto. Soc., Univ. Minn., Aug. 24-28.

Van Arsdel, E.P., A.J. Riker, T.F. Kouba, V.E. Suomi, and R.A. Bryson. 1961. The climatic distribution of blister rust on white pine in Wisconsin. US For. Serv., Lake States Stat. Pap. 87, $34 \mathrm{p}$

\section{Buy The Original MULTIPOT And Save! \\ The Original MULTIPOT is priced lower than any other

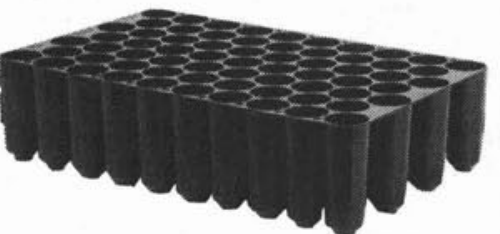
available.

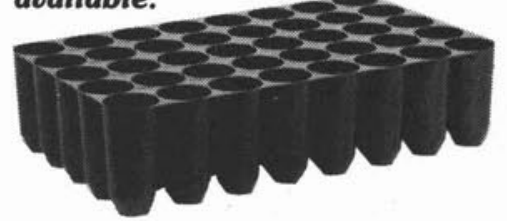

It has been used and proven for over 20 years in Scandinavia and North America.

Made of high density, rigid poly-ethylene, it can be reused up to six times or more!

The Original MULTIPOT has a $33 \%$ larger cavity volume than other makes. Its wider, more shallow cavity produces a sturdier root system better able to take advantage of ground surface heat, giving seedlings a higher survival rate.

Sizes are available up to $40 \mathrm{~mm}$ cavity dia., $93 \mathrm{~cm}^{3}$ cavity volume, and a $19 \mathrm{~mm}$ pruning hole dia., resulting in a better root system.

Convenient Handling Systems are also available for transporting MULTIPOTS in the field to the planting site.

For further details about the original MULTIPOT please call:
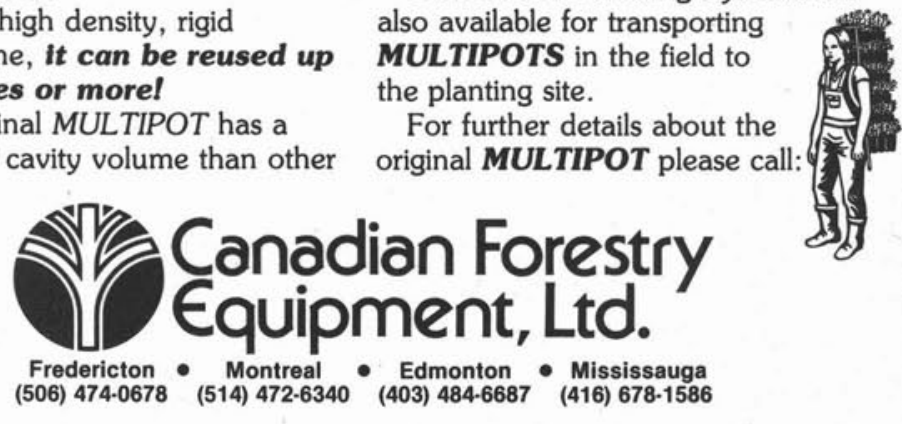